Vol. 11 (2): 321-326 (2021)

\title{
PROPERTIES COMPARISON OF TWO ACID-ACTIVATED BENTONITES OF KOSOVO TO BE USED AS BLEACHING AGENTS
}

\author{
Valdet Teneqja $^{1}$, Arjan Korpa ${ }^{2}$, Spiro Drushku ${ }^{3}$, Kledi Xhaxhiu ${ }^{2}$, Enkeleida Skënduli $^{2}$ \\ ${ }^{1 *}$ Laboratory "Ex Fis Labs", Pristina, Kosovo; \\ ${ }^{2 * U n i v e r s i t y ~ o f ~ T i r a n a, ~ F a c u l t y ~ o f ~ N a t u r a l ~ S c i e n c e s, ~ D e p a r t m e n t ~ o f ~ C h e m i s t r y, ~ A l b a n i a ; ~}$ \\ ${ }^{3}$ University of Tirana, Faculty of Natural Sciences, Department of Industrial Chemistry, Albania; \\ *Corresponding Author Arjan Korpa, e-mail: arjan.korpa@fshn.edu.al;
}

Received February 2021; Accepted March 2021; Published April 2021;

DOI: https://doi.org/10.31407/ijees11.217

\begin{abstract}
This paper presents a summary of the results of activation of two Kosovo bentonites mainly in the Goshica area and the Karaqeva area. The two bentonites have been modified by introducing optimal bentonite processing methods including acid activation, in order for them to be used as bleaching agents. They have been compared with each other and with the untreated natural bentonites. The mass percentage of $\mathrm{H}_{2} \mathrm{SO}_{4}$ in the bentonite-acid mixture varied from 10, 30 and 50\% (in weight ratios). It was found that the activation of bentonites brings about significant changes in their structure and physico-chemical properties. The specific surface area and cationic exchange capacity correlate well with the amount of activator. Acid activated Kosovo bentonites show promising results to be used for industrial processing, bleaching agents and UMO recycling.
\end{abstract}

Keywords: Properties comparison, Acid activated, Kosovo Bentonites, Bleaching agents. 